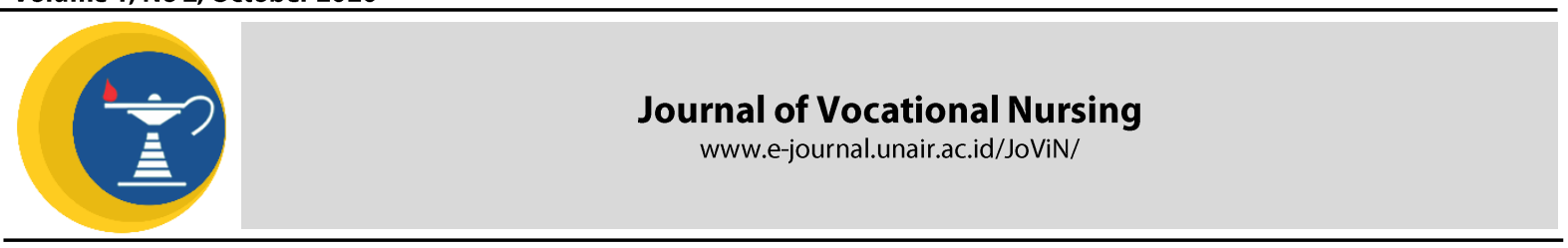

\title{
RESILIENCE AMONG DRUG ABUSER UNDER TREATMENT PROGRAM IN DRUG REHABILITATION CENTER IN SURABAYA
}

\author{
Fauziah Fitri Hernanto ${ }^{1}$, Agung Putri Harsa SN ${ }^{2}$, Roby Aji Permana ${ }^{3}$ \\ 1,2,3 Faculty of Health Science, Universitas Merdeka Surabaya
}

Research Report

\section{ABSTRACT}

Introduction: Drug abuse is very dangerous because it disrupts the ability to thinking process. Drugs have three dangerous characteristics, namely, addiction, tolerance, and habituation that cause an addict to be compelled to continue using drugs or to try drugs again. A former drug addict is prone to experience inability to pass through stress and stress due to symptoms of neurological dysfunction, physical craving suggestions, and loss of support from the environment. To deal with this situation, former drug addicts must defend themselves by bringing up a source of strength from within themselves called resilience. Increased self-resilience will help former drug addicts to cope with the difficulties experienced, times of crisis, avoid addiction, and overcome stress triggers. Methods: This study used a descriptive design and the sample size was 30 respondents with purposive sampling. The variables of this study was resilience measured through the questionnaire. Results: The results of descriptive analysis show that 16 (53.3\%) respondents have low resilience, 6 (20\%) respondents have very low resilience, and 8 (26.7\%) respondents have sufficient resilience. Conclusion: The conclusion of this study is that most former drug addicts have low resilience. Health workers and facilitators play an important role in fostering the resilience of former drug addicts.
ARTICLE INFO

Recived 21 October 2020

Accepted 28 October 2020

Online 29 October 2020

*Correspondence:

Fauziah Fitri Hernanto

*Email:

zii.uchi25@gmail.com

Keywords:

Resilience, Drugs, Rehabilitation

\section{INTRODUCTION}

Drug abuse can interfere the person's physical and psychological capacities trough their life. Drugs abuses not only threaten the health of addicts and society, but also ease the way to the moral and intellectual corruption that can have dangerous consequences for the health of the consumer. Psychological problems that can occur on drug abusers are disorders of the thought process. Drugs have three dangerous effects. That is addiction, tolerance, and habituation. The effect of these three characteristics can cause an abuser to have no control over him self, resulting in the desire to use drugs continuously or experience the feeling of wanting to try again after a certain period of time. (Corps, 2018; Partodiharjo, 2010). This is one of the psychological effects of drug addiction involved in craving of the drug. Craving is an effect of drug addiction whereby the addict is obsessed with obtaining and using the drug, to the exclusion of all else.
United Nations Office on Drugs and Crime (UNODC) record that there are at least 271 million people worldwide or $5.5 \%$ of the world's population (UNODC, 2019). Data form The National Narcotics Board of the Republic of Indonesia periodically every three years show that, The prevalence rate for narcotics from 2011 to 2019 has decreased quite significantly. In 2011 the prevalence was $2.23 \%$, in 2014 the prevalence was $2.18 \%$, in 2017 it was $1.77 \%$ and in 2019 it was $1.80 \%$ (Badan Narkotika Nasional, 2019).

Drugs addict or abuser will experience an inability to pass through stress due to symptoms of brain dysfunction such as memory impairment, decreased concentration power and physical craving suggestions (the desire to use drugs again). This inability is also exacerbated by the loss of support and strength from the surrounding environment (Fitrianti, Subekti, \& Aquarisnawati, 2011; Partodiharjo, 2010). To deal with this situation, a former drug addict must have selfdefense by bringing out a source of strength from 
within him. The ability of a person to stand firm in the midst of difficult conditions is called resilience (Safitri, 2015)

Self-resilience will help drug addicts or abusers to withstand the difficulties that they experienced, times of crisis, avoid addiction, and overcome stressful things (Nurmilasari, 2018). Resilience will equip individuals with additional protection and the ability to cope with problems as a result of the situation at hand by creating selfresilience and can help former drug addicts to return to their roles in society, be able to make sense of life better, and avoid relapse. People who have resilience often restore to the normal situation after experiencing negative emotions as a result of stressful encounters. Resilient individuals leave behind stressful events without facing any problems in mental health (Arce et al., 2019).

Evidence suggests that resilient people have a better mental health status; have greater self-regulatory skills; higher self-esteem; greater parental support; and are less likely to get involved in high-risk behaviors such as drug abuse (Cuomo, Sarchiapone, Giannantonio, Mancini, \& Roy, 2008; Fadardi, Azad, \& Nemati, 2010). The aim of this study was to identify resilience scale among drug abuser under treatment program in drug rehabilitation center, Yayasan Bambu Nusantara Surabaya.

\section{MATERIALS AND METHODS}

This research was using a descriptive study design. The number of samples in this study were 30 clients who were undergoing rehabilitation at the Bambu Nusantara Surabaya Foundation who were selected through purposive sampling. The inclusion criteria used were that the research subjects had experienced drug dependence, stopped using drugs for at least 2 years (Partodiharjo, 2010), can read and write, and is willing to be involved in research. The research variable is resilience which is measured using the questionnaire instrument The Resilience Scale which is composed of the parameters of inner balance, perseverance, independence, meaningfulness, existential loneliness. The resilience instrument consists of 25 questions with the answer choices provided consist of choices ranging from 1 to 7 with the assumption that the distance or interval between numbers with an equivalent number starts from indicating strongly disagree to strongly agree starting from numbers 1 to 7 . From these items, then given a score with an average value of 25 to 175 which shows the number of how high the resilience of a person is with the item analysis score categories into 6 categories, namely very low (25-100), low (110115), almost low (116- 130), moderate (131-145), high (146-160), very high (161-175). The research data were analyzed descriptively by describing the distribution of the results of the data measurements carried out by the researcher. The ethical principles used in this study are informed consent, anonymity, confidentiality, benefit and non-maleficence.

\section{RESULTS}

Table 1 Distribution of characteristics of respondents under rehabilitation at Yayasan Bambu Nusantara Surabaya.

\begin{tabular}{ccccc}
\hline No & Variable & Category & Frequency (n) & Percentage \\
\hline 1 & Age & Child & 0 & 20 \\
& Teenage & 3 & 40 \\
& Adult & 21 & \\
& & 6 & 100 \\
& Elder & 30 & 70 \\
& & 21 & 30 \\
\hline 2 & Total & Men & 9 & 100 \\
\hline & Gender & Women & 30 & 13,3 \\
& Total & & 4 & 20 \\
\hline 3 & Education level & Elementary School & 6 & 56,7 \\
& & Junior High School & 17 & 10 \\
\hline & & Senior high School & 3 & 100 \\
\hline & College & 30 &
\end{tabular}


Descriptive analysis was carried out by identifying the characteristics of the respondents including age, gender and education level. The results of the descriptive analysis show that most of the respondents are male and are in the adult age range according to the age category. Most of the respondents have a high school level of education.

Table 2. Distribution of resilience in respondents under rehabilitation at Yayasan Bambu Nusantara Surabaya.

\begin{tabular}{cccc}
\hline No & Category & Frequency $(\mathbf{n})$ & Percentage \\
\hline 1 & Very low & 6 & 20 \\
2 & Low & 16 & 53,3 \\
3 & Enough & 8 & 26,7 \\
4 & High & 0 & 0 \\
5 & & 0 & 0 \\
\hline & Very high & 30 & 100 \\
\hline
\end{tabular}

Shows the results of descriptive analysis on the resilience variable of former drug addicts undergoing rehabilitation at the Bambu Nusantara Foundation. The results of the analysis illustrate that most of the respondents have low category resilience, namely $16(56.3 \%)$ respondents. Fourteen other respondents are in the very low category ( 6 respondents) and in the moderate category (8 respondents). The results of the analysis show that there are no respondents who have high and very high resilience score.

\section{DISCUSSION}

The results of this study showed that the measurement of respondent resilience before the intervention was in the low category. Resilience in this category indicates that drug addict face difficulties in undergoing the psychological recovery process due to the burden of worrying about living in the future. Former drug addicts experience a difficult process where they must be able to let go of their dependence on drugs and adapt to get back into society to run their lives.

There are two processes that can go through in order to stop using drugs. First, there is an impulse from within, namely, feelings of shame and guilt begin, both with family and the environment (Junaiedi, 2012). Second, through their family or othetr people. In this study, respondents who were former drug addicts were in the adult age classification. This may be because early adulthood development tasks such as starting work, choosing a partner, starting a family, raising children, and managing a household make addicts who have entered this age more responsible, thus encouraging them to recover and get off drugs. Drug abuse has confirmed the decrease in the rate of ego control and resilience (Roustaei et al., 2017). Evidences proposed that resilience people have a better mental health status; have greater self-regulatory skills; higher self-esteem; greater parental support; and are less likely to get involved in high-risk behaviors such as drug abuse (Bernad et al., 2018).

The resilience can be defined as the absence of psychopathology despite exposure to high stress and reflects a person's ability to cope successfully in the face of adversity, demonstrating adaptive psychological and physiological stress responses. Addiction disorders of drugs is rooted in the neurotoxic effects of stress on the brain. These effects undermine the neuroplasticity within networks required for the recovery process to take place. As a result, mechanisms of resilience are crucial to the understanding of neuroadaptive potential and its behavioral consequences (Alim et al., 2005; Zamani, Nasir, Desa, Khairudin, \& Yusooff, 2014).

There are seven parameters that establish resilience, namely emotion regulation (the ability to manage emotions when facing stressful conditions), impulse control (individual ability to make decisions quickly, control desires, actions, behavior in difficult circumstances), optimism (individuals always have a good view. in dealing with everything that happens), causal analysis (the individual is able to identify problems accurately), empathy (the individual's ability to feel the psychological and emotional conditions of others), self-efficacy (the belief that the individual is able to solve the problems experienced), and reaching out (ability to overcome obstacles and achieve positive aspects of the problem at hand) (Rudzinski, McDonough, Gartner, \& Strike, 2017).

Resilience to respondents is also related to risk factors and protective factors. The combination of these risk factors and protective factors forms the resilience of a person. Risk factors are factors that worsen a person's condition and increase the likelihood of maladaptive behavior. Protective factors are factors that play a protective role in reducing the impact of risk factors in a person's life to increase resilience. Protective factors are internal strengths and external resources that interact with risks to affect the chances of negative outcomes for individuals. 
(Alim et al., 2005; Ikanovitasari \& Sudarji, 2017; Made, Sulistiowati, Keliat, \& Wardani, 2010; Rudzinski et al., 2017). The protective factors that can be identified in present study are the knowledge, experience and social support received by respondents during rehabilitation.

Therefore, resilience process can reform, adjust or even disappear unpleasant effects that results in poor mental health of the injured persons. Resilience training can adjust the stress level and disability in unpleasant circumstances. Studies showed that resilience training can be useful for persons to behave in front of difficult circumstances in a flexible manner (Friborg, Barlaug, Martinussen, Rosenvinge, \& Hjemdal, 2015; Tugade \& Fredrickson, 2014).

The effort that can be made by conselor or care giver are to provide an understanding of resilience capabilities and ways to improve them. Research by Morris, Simpson, Sampson, \& Beesley (2014) found that, positive compatibility with life is referred to as resilience training. Also, bouncing back and going strong can result in high level of resiliency training. Hardiness plays an important role in person's recovery from stress and addiction. Implications for the research findings showed that clients that are undergoing the drug rehabilitation treatment or interventions that comprised of counselling would have an effect on the level of family resiliency. Health workers, caregiver, and conselor have a role to help patients commit to the decisions and goals they want to achieve through a therapeutic communication process and respondents must be able to stick with what they have chosen because they have made commitments so that it will affect the respondent's psychological response and coping to react to stressors and pressure experienced (Nurfatimah, Filliani, \& Karsih, 2016).

\section{CONCLUSION}

The conclusion of this study is that drug abuser under treatment program in drug rehabilitation center at the Bambu Nusantara Surabaya still have low level of resilience. Researchers hope that this research can help or caregiver counselors to get an idea of the condition of former drug addicts, so it is hoped that the counselors can read and understand the whole research that the researchers conducted. For counselors, it is generally recommended that they be able to provide services in the form of guidance and counseling with the aim of fostering and training the resilience abilities of each drug abuser.

\section{REFERENCES}

Alim, T. N., Lawson, W. B., Feder, A., lacoviello, B. M., Saxena, S., Bailey, C., ... Neumeister, A. (2005). Resilience to Meet the Challenge of Addiction Psychobiology and Clinical Considerations. Alcohol Research: Current Reviews, 506-515.

Arce, E., Simmons, A. N., Stein, M. B., Winkielman, P., Hitchcock, C., \& Paulus, M. P. (2019). Association between individual differences in self-reported emotional resilience and the affective perception of neutral faces. Journal of Affective Disorders, 114(1), 286-293.

Badan Narkotika Nasional. (2019). Press release akhir tahun 2019. BNN, pp. 1-33. Retrieved from https://bnn.go.id/konten/unggahan/201 9/12/DRAFT-LAMPIRAN-PRESS-RELEASEAKHIR-TAHUN-2019-1-.pdf

Bernad, R., Talens, F., Geraci, I., Julián, M., Yuncal, R., \& Ramos, M. (2018). Housing First Elements Facilitating Resilience in Clients with Addictions in the Habitat Programme: a Qualitative Study. European Journal of Homelessness, 12(1), 101-120.

Corps, M. (2018). Measuring Gender Dynamics In Resilience: Tools for integrating gender into resilience-focused programs: Summary of Study conducted by consultant Marthe Doka with Mercy Corps Niger's BRIGE program. Portland OR: Mercy Corps.

Cuomo, C., Sarchiapone, M., Giannantonio, M. D., Mancini, M., \& Roy, A. (2008). Aggression, impulsivity, personality traits, and childhood trauma of prisoners with substance abuse and addiction. American Journal of Drug and Alcohol Abuse, 34(3), 339-345.

Fadardi, J. S., Azad, H., \& Nemati, A. (2010). The relationship between resilience, motivational structure, and substance use. Procedia - Social and Behavioral Sciences, 5, 1956-1960. https://doi.org/10.1016/j.sbspro.2010.07. 395

Fitrianti, N., Subekti, E. M. A., \& Aquarisnawati, P. (2011). Pengaruh antara Kematangan Emosi dan Self-eficacy terhadap Craving pada Mantan Pengguna Narkoba. INSAN, 13(02), 106-117.

Friborg, O., Barlaug, D., Martinussen, M., Rosenvinge, J. H., \& Hjemdal, O. (2015). Resilience in relation to personality and intelligence. Int Journal Methods Psychiatr Res, 14(1), 29-42. 
Hayes, S., Jason, B., W., F., Akihiko, M., \& Jason, L. (2006). ACT: Model, Processes and Outcome. Journal of Behaviour Research and Therapy, 44, 1-25.

Ikanovitasari, C., \& Sudarji, S. (2017). Gambaran resiliensi pada mantan pengguna narkoba. Prosiding Temu IImiah X Ikatan Psikologi PErkembangan Indonesia, 100115.

Junaiedi. (2012). Makna Hidup pada Mantan Pengguna Napza. Fakultas Psikologi Universitas Gunadarma: Jakarta.

Made, N., Sulistiowati, D., Keliat, B. A., \& Wardani, I. Y. (2010). Pengaruh Acceptance and Commitment Therapy terhadap Gejala dan Kemampuan Klien dengan Resiko Perilaku Kekerasan. Jurnal Keperawatan Jiwa, 2(1), 51-57.

Morris, C., Simpson, J., Sampson, M., \& Beesley, F. (2014). Cultivating positive emotions: $A$ useful adjunct when working with people who self-harm? Clin Psychol Psychother, 21(4), 352-264.

Nurfatimah, U., Filliani, R., \& Karsih, K. (2016). Profil Resiliensi Mantan Pecandu Narkoba (Studi Kasus di Balai Besar Rehabilitasi Narkoba, BNN, Lido). Insight: Jurnal Bimbingan Konseling, 4(2), 110-116. https://doi.org/10.21009/insight.042.19

Nurmilasari, D. (2018). Dukungan sosial keluarga dan resiliensi mantan pecandu napza skripsi. Universitas Islam Riau.

Partodiharjo. (2010). Kenali Narkoba dan Musuhi Penyalahgunaannya. Jakarta: Erlangga.
Roustaei, A., Bakhshipoor, B., Doostian, Y., Goodiny, A., Koohikar, M., \& O, M. (2017). Effectiveness of Resilience Training on Ego-control and Hardiness of Illicit Drug Users. Addict Health, 9(1), 24-31.

Rudzinski, K., McDonough, P., Gartner, R., \& Strike, C. (2017). Is there room for resilience? A scoping review and critique of substance use literature and its utilization of the concept of resilience. Substance Abuse: Treatment, Prevention, and Policy, 12(1), 1-35. https://doi.org/10.1186/s13011017-0125-2

Safitri, L. D. (2015). Resiliensi Pada Mantan Penyalahguna Napza di Yogyakarta. Universitas Negeri Yogyakarta.

Tugade, M., \& Fredrickson, L. (2014). Resilient individuals use positive emotions to bounce back from negative emotional experiences. J Pers Soc Psychol, 86(2), 320-333.

UNODC. (2019). World Drug Report 2019. Retrieved from https://wdr.unodc.org/wdr2019/prelaun ch/WDR-2019-Methodology-FINAL.pdf

Zamani, Z. A., Nasir, R., Desa, A., Khairudin, R., \& Yusooff, F. (2014). Family Functioning, Cognitive Distortion and Resilience among Clients under Treatment in Drug Rehabilitation Centres in Malaysia. Procedia - Social and Behavioral Sciences, 140, 150-154. https://doi.org/10.1016/j.sbspro.2014.04. 401 